\title{
(IN)DEVIDO PROCESSO: PRECEDENTES E TECNOLOGIA EM UM SISTEMA JUDICIARIO SOBRECARREGADO
}

\section{(UN)DUE PROCESS: PRECEDENTS AND TECHNOLOGY IN AN OVERBURDENED JUDICIAL SYSTEM}

\section{(IN)DEBIDO PROCESO: PRECEDENTES Y TECNOLOGÍA EN UN SISTEMA JUDICIAL SOBRECARGADO}

\section{Edilson Vitorelli ${ }^{1}$}

\section{Luís Henrique Bortolai²}

Licença CC BY:

Artigo distribuído sob os termos Creative Commons, permite uso e distribuição irrestrita em qualquer meio desde que o autor credite a fonte original.

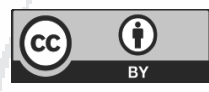

Resumo: Este trabalho pretende analisar os efeitos da introdução de ferramentas tecnológicas e de precedentes obrigatórios em um sistema processual sobrecarregado. Toma-se como ponto de partida o sistema judicial brasileiro, do qual se traça um panorama. Realizam-se estudos quantitativos em três tribunais nacionais, por meio de uma pesquisa empírica amostral e de julgados, averiguando prevalência de teses restritivas de demanda. Analisam-se, qualitativamente três casos que denotam formas, por intermédio das quais os precedentes obrigatórios podem ser utilizados para desestimular a propositura de novas ações. Também se verifica que o discurso judicial fomenta a preocupação com a quantidade de decisões, em detrimento da qualidade. Conclui-se que esses fatores são capazes de induzir vieses cognitivos favoráveis a julgamentos de improcedência, privando os autores de direitos que, em outras circunstâncias, Ihes poderiam ser reconhecidos.

1 Pós-doutorado em direito pela Universidade Federal da Bahia, com estudos no Max Planck Institute for Procedural Law. Doutor em direito pela Universidade Federal do Paraná, mestre pela Universidade Federal de Minas Gerais. Visiting scholar na Stanford Law School e visiting researcher na Harvard Law School. É o único autor brasileiro vencedor do prêmio Mauro Cappelletti, atribuído pela International Association of Procedural Law ao melhor livro sobre processo do mundo. Professor da Universidade Presbiteriana Mackenzie e da Universidade Católica de Brasília (graduação e mestrado). Procurador da República.I. E-mail: edilsonvitorelli@gmail.com

2 Doutor e Mestre em Acesso à Justiça pela FADISP (Faculdade Autônoma de Direito). Especialista em Direito Tributário e Bacharel em Direito pela PUC - Campinas (Pontifícia Universidade Católica de Campinas). Pósgraduado em Gestão do Ensino Superior e Educação pela Centro Universitário UniMetrocamp. Professor de Direito e Coordenador do Núcleo de Prática e Atividades Complementares do Centro Universitário UniMetrocamp - YDUQS. Assessor da Procuradoria da República em Campinas. Campinas - São PauloE-mail: luis.bortolai@ gmail.com 
Palavras-chave: Precedentes; Tecnologia; Vieses cognitivos; sobrecarga judicial.

Abstract: This paper analyzes the effects of the introduction of technological tools and mandatory precedents on an overloaded procedural system. It takes as its starting point the Brazilian judicial system, from which we draw general conclusions. We conducted quantitative studies in three national courts, verifying the prevalence of rulings that restrict future cases, probably in an effort to compensate for the already existing overload. We also conducted a qualitative analysis of three cases that suggest that obligatory precedents can - and, in our opinion, were - used to discourage the filing of new lawsuits. We found that judicial discourse fosters a concern for the quantity of decisions rather than their quality. In conclusion, we affirm that these factors are capable of inducing cognitive biases that favor judgments of inadmissibility, depriving citizens of rights that, in other circumstances, would be recognized.

Keywords: Precedents; Technology; Cognitive biases; judicial overload.

Resumen: Este trabajo pretende analizar los efectos de la introducción de herramientas tecnológicas y de precedentes obligatorios en un sistema procesal sobrecargado. Se toma como punto de partida el sistema judicial brasileño, del cual se traza un panorama. Se realizan estudios cuantitativos en tres tribunales nacionales, por medio de una investigación de muestra empírica y de juzgados, averiguando predominio de tesis restrictivas de demanda. Se analizan, cualitativamente tres casos que denotan formas, por intermedio de las cuales los precedentes obligatorios pueden ser utilizados para desestimular la proposición de nuevas acciones. También se verifica que el discurso judicial incentiva la preocupación con la cantidad de decisiones, en detrimento de la calidad. Se concluye que esos factores son capaces de inducir sesgos cognitivos favorables a sentencias infundadas, privando los autores de derechos que, en otras circunstancias, les podrían ser reconocidos.

Palabras clave: Precedentes; Tecnología; Sesgos cognitivos; sobrecarga judicial.

\section{INTRODUÇÃO}

Este artigo pretende abordar, a partir de levantamentos empíricos, o impacto da introdução de precedentes vinculantes e de inovação tecnológica em um sistema processual altamente sobrecarregado. Valendo-se de uma metodologia baseada na análise de amostra de julgados de tribunais de segunda instância e superiores, de diversas regiões do Brasil, objetiva-se realizar uma análise quantitativa e qualitativa tendo como enfoque a identificação de impactos das técnicas de formação de precedentes vinculantes e dos recursos tecnológicos no sistema processual brasileiro.

A globalização tem acarretado dois impactos imediatos sobre o processo civil. Primeiro, a solução de problemas processuais tem sido continuamente transplantada de um país para outro. Assim, por exemplo, países de Civil Law vêm introduzindo, progressivamente, soluções variadas de precedentes judiciais obrigatórios, característicos de países de Common Law. Segundo, as soluções tecnológicas desenvolvidas em um país são, rapidamente, expandidas para outros. 
Ferramentas de big data, inteligência artificial e processo eletrônico passaram a ser temas de atenção da comunidade processual global. O problema é que essas inovações não se expandem no vácuo. Elas encontram tradições processuais, contextos sociais e culturais distintos, o que impacta sobre o modo como são incorporadas ao sistema.

Em assim sendo, este trabalho pretende avaliar os efeitos da introdução de ferramentas tecnológicas e de precedentes obrigatórios em sistemas processuais quantitativamente sobrecarregados, a partir da hipótese de que essas ferramentas têm potencial para reforçar no Poder Judiciário a propensão para negar direitos, para julgar improcedentes os pedidos apresentados. A improcedência funcionaria, nesse caso, como mecanismo de restrição da demanda judicial, desestimulando novos ajuizamentos. Se confirmada, a hipótese sugere que a tecnologia, aliada a um sistema de precedentes, poderá transformar o acesso à justiça em uma ilusão: todos ingressam, muitos julgamentos são realizados em breve tempo, mas poucos vencem. A transformação social que o Poder Judiciário poderia produzir deixa de acontecer.

O artigo é iniciado com uma exposição do panorama do sistema jurisdicional brasileiro e sua sobrecarga, seguido do cenário de introdução dos precedentes vinculantes e das soluções tecnológicas. A seguir, parte-se para a verificação da hipótese, adotando como metodologia uma análise amostral qualitativa e quantitativa de precedentes vinculantes, colhidos de alguns tribunais brasileiros, destacando o ramo do direito e o teor da decisão. A discussão, que conclui o texto, explora evidências empíricas acerca da possibilidade de que a vinculação por precedentes e os recursos tecnológicos possam incrementar os riscos de vieses cognitivos favoráveis às decisões de improcedência, que desestimulariam novos ajuizamentos.

\section{PANORAMA DO SISTEMA JURISDICIONAL BRASILEIRO}

O cenário do sistema processual brasileiro é único no mundo. Em 2017, o sistema contava com 80,1 milhões de processos em andamento, sob responsabilidade de 18 mil juízes. Isso significa, em média, um pouco mais de 4 mil processos por juiz, incluindo os casos sob apreciação da justiça federal e das justiças estaduais, bem como dos ramos da justiça especializados por matéria (direito do trabalho, direito eleitoral e direito penal militar). ${ }^{3}$

Esses números são representativos do sucesso do processo civil brasileiro quanto aos desafios do acesso à justiça, mapeados pelo Projeto Florença, na década de 1970, sob a coordenação de Mauro Cappelletti e Bryant Garth 4 . O sucesso do Brasil é marcante em relação àquilo que os autores classificaram como primeira "onda renovatória" do acesso à justiça. O processo é barato, as normas de gratuidade judiciária são amplas, e os serviços advocatícios privados estão disponíveis a custo

3 CONSELHO NACIONAL DE JUSTIÇA. Justiça em números: 2018. Disponível em http://www.cnj.jus.br/files/ conteudo/arquivo/2018/08/44b7368ec6f888b383f6c3de40c32167.pdf. Acesso em: 21 maio 2019.

4 CAPPELlETTI, M.; GARTH, B. Access to Justice: A World Survey. Milano: Giuffrè, Sitjoff and Noordhoff, 1978. p. 25. 
relativamente baixo, dado o grande número de profissionais formados e o grande número de faculdades de Direito existentes. Em termos comparativos, o sucesso do Brasil em termos de acesso à justiça é muito superior ao dos países europeus ${ }^{5}$.

Mesmo para os indivíduos incapazes de custear o serviço privado, o Estado disponibiliza defensorias públicas, cujo serviço é totalmente gratuito, em todos os ramos da justiça. Qualquer pessoa com renda familiar per capita mensal inferior a aproximadamente US\$ 500 pode usufruir de serviços públicos de advocacia, tanto para processos cíveis, quanto criminais. Qualquer pessoa que declarar não ter recursos para arcar com as despesas do processo será desobrigada de adiantá-las.

A amplitude do acesso à justiça é verificada pela propositura, em 2017, de 12 mil processos para cada 100 mil habitantes. Além disso, o Conselho Nacional de Justiça estimou que, dos processos encerrados em 2017, 33\% (trinta e três por cento) foram litigados gratuitamente 6 . O índice de processos que tramitam gratuitamente cresceu 05\% (cinco por cento) entre 2015 e 2017. Assim, não apenas se litiga muito, como também se litiga, com grande frequência, graciosamente.

A segunda "onda renovatória", que considera a possibilidade de se litigar processos relativos a direitos transindividuais, do mesmo modo foi amplamente concretizada no País. Isso se deve a uma norma constitucional que ampliou a independência do Ministério Público para incluir, além da matéria penal, os processos relacionados a direitos difusos, coletivos e individuais homogêneos. Assim, no Brasil, a maioria das class actions (como se diz nos EUA) ou das ações de collective redress (como se diz na Europa), é proposta pelo Ministério Público e não por agentes privados ou órgãos regulatórios.

Essa independência constitucional do Ministério Público se caracteriza pela plena autonomia entre os seus membros, tal como ocorre com os juízes, bem como pela autonomia administrativa e financeira do órgão em relação ao Poder Executivo. Por isso, são usuais ações civis indicadas para perseguir direitos difusos, coletivos e individuais homogêneos, relacionados ao meio ambiente, ao patrimônio histórico e cultural, ao direito à saúde e à educação, dentre outros temas. Não raramente, essas ações são propostas contra o próprio Estado ou contra algumas das maiores empresas do País. Além da autonomia, o Ministério Público desfruta, ainda, de gratuidade judiciária, o que permite que essas ações sejam propostas sem grandes constrições orçamentárias.

Em 2017, o Ministério Público brasileiro conduziu mais de 250 mil investigações relativas a violações de direitos difusos e coletivos, tendo como investigados tanto entes privados quanto entes públicos. Em razão da já mencionada autonomia, tais investigações ocorrem de forma independente e imparcial, tanto contra entes governamentais, quanto contra particulares. Essas 250 mil investigações originaram mais de 40 mil ações propostas e mais de 12 mil acordos (denominados compromissos de ajustamento de conduta), no ano de 2017. Assim, os dados empíricos permitem afirmar que o Brasil cumpriu, de maneira exemplar, as indicações de ampliação do acesso à justiça, tal como formuladas pelo Projeto Florença, na década de 1970, também em relação à segunda "onda renovatória".

$5 \quad$ Ver Zuckerman, Adrian (org.). Civil Justice in Crisis. London: Oxford University Press, 2000; RHODE, Deborah. Access to Justice. London: Oxford University Press, 2004.

6 CONSELHO NACIONAL DE JUSTIÇA. Justiça em números: 2018. Disponível em http://www.cnj.jus.br/files/ conteudo/arquivo/2018/08/44b7368ec6f888b383f6c3de40c32167.pdf. Acesso em: 21 maio 2019. p. 82 
Todavia, como diria Milton Friedman, "there is no such thing as a free lunch ${ }^{7}$ (Tradução livre: não existe almoço grátis). Ao permitir que o Poder Judiciário fosse amplamente acessível, tanto para demandas individuais, quanto para demandas coletivas, em um país com mais de 200 milhões de habitantes, o número de processos em andamento aumentou progressivamente. Hoje em dia, com mais de 80 milhões de processos em andamento, o Poder Judiciário nacional mergulhou no caos. A lentidão é o problema mais facilmente visível. Em média, um processo leva quase 08 anos para chegar a uma decisão definitiva. Se for necessário o cumprimento forçado da decisão - o que ocorre com frequência - o processo pode levar mais 07 anos $^{8}$. Não é incomum, portanto, encontrar casos que estão na justiça há 10 ou 15 anos. Em muitas situações, todo esse tempo é perdido. Há indicativos de que, por variados motivos, um significativo percentual de casos não resulta em concreta satisfação do direito reconhecido em favor do vencedor?

Além disso, a oralidade do processo foi praticamente abandonada. Os juízes não seriam capazes de fazer o número de audiências necessárias à decisão de todos os casos. Por isso, o processo se tornou predominantemente escrito. As provas e os argumentos das partes são apresentados, em regra, em manifestações escritas, reservando-se as audiências apenas para a oitiva de testemunhas. As partes, em muitos casos, nunca ficam diante do juiz. Em terceiro lugar, os juízes são submetidos a uma carga de trabalho que não encontra equivalente no mundo, em todos os graus de jurisdição. As duas cortes superiores do País, o Supremo Tribunal Federal (responsável pela interpretação final da Constituição) e o Superior Tribunal de Justiça (responsável pela interpretação final da lei federal) proferem, respectivamente, mais de 100 mil e mais de 500 mil decisões por ano, o que significa mais de 10 mil decisões por juiz/ministro, por ano. Em uma divisão matemática, isso significa decidir entre 50 e 100 casos por dia útil de trabalho de cada juiz. Faz-se, em um dia, o que a Suprema Corte dos Estados Unidos faz em um ano.

Essa produtividade é viabilizada tão só pela existência de grandes equipes de assessoria, que se encarregam da efetiva redação da decisão, a qual é apenas conferida e assinada pelos juízes. O quanto isso compromete a qualidade das decisões tomadas é um tema que ainda carece de estudos científicos.

Em quarto lugar, o custo de manutenção da estrutura jurisdicional é bastante elevado, sobretudo quando considerado no contexto do índice de desenvolvimento nacional. O Poder Judiciário custou, em 2017, R\$ 76,5 bilhões por ano (aproximadamente US\$ 20 bilhões), o que significa R\$368,22 (US\$ 90) por habitante e equivale a 1,2\% do PIB nacional. Esse índice, em proporção do PIB, é superior à maioria dos países europeus e supera o dobro da média dos países da OCDE. Embora essa comparação tenha suas distorções, não há como negar que o Poder Judiciário brasileiro custa caro para o País.

7 FRIEDMAN, M. There's no such thing as a free lunch. Chicago: Open Court Pub, 1975.

8 CONSELHO NACIONAL DE JUSTIÇA. Justiça em números: 2018. Disponível em http://www.cnj.jus.br/files/ conteudo/arquivo/2018/08/44b7368ec6f888b383f6c3de40c32167.pdf. Acesso em: 21 maio 2019.

9 Levantamento do Instituto de Pesquisa Econômica Aplicada - IPEA - constatou que, em relação aos processos judiciais que pretendem cobrar dívidas tributárias, o índice de satisfação é de cerca de $0,5 \%$ (meio por cento). A cada 200 processos, um é capaz de satisfazer o credor. INSTITUTO DE PESQUISA ECONÔMICA APLICADA IPEA. Custo Unitário do Processo de Execução Fiscal na Justiça Federal. Brasília: IPEA, 2012. 
Em síntese, o Brasil ampliou significativamente o acesso à justiça, todavia agora que as pessoas a acessaram, o Judiciário não consegue dar conta de oferecer uma resposta.

\section{O CPC HÁ DE SALVAR-NOS: UM SISTEMA DE PRECEDENTES JUDICIAIS OBRIGATÓRIOS PARA O BRASIL}

Em 2015, após quatro anos de discussões, foi aprovado um novo Código de Processo Civil brasileiro, para substituir o que vigorava desde 1974. Sua tramitação foi conduzida pelo Ministro do Supremo Tribunal Federal Luiz Fux, o qual repetiu, incessantemente, em diversos veículos de comunicação, a promessa de que o Código acarretaria mais agilidade para o Poder Judiciário.

Apesar desse discurso, boa parte do texto do Código repete o seu antecessor. Na parte em que houve mudanças, muitas delas foram embasadas em escritos acadêmicos dos juristas integrantes da comissão de redação. Quase nada se fez com embasamento em pesquisas empíricas. O Poder Judiciário, aliás, pouco participou das discussões acerca do Código, talvez pela falta de inclinação dos juízes para debates políticos ${ }^{10}$. Uma das mudanças mais significativas, propostas pelo CPC, foi o aprofundamento de um sistema de precedentes judiciais obrigatórios, o qual deu sequência a um movimento iniciado em 1993 e expandido em 2004. Esse sistema consiste na produção, pelos tribunais, de decisões judiciais, cujo conteúdo é obrigatório para os demais juízes a eles inferiores. A premissa dessa proposta, nunca demonstrada cientificamente, é a de que, como os juízes desobedecem aos entendimentos dos tribunais superiores, por isso é necessário reforçar sua normatividade. Se as decisões dos tribunais superiores forem obrigatórias, garante-se uniformidade do sistema.

Assim, ao contrário do que ocorreu na história dos países de Common Law, o sistema brasileiro de precedentes não nasceu da preocupação de produzir normas jurídicas para os casos concretos, mas como uma ferramenta de gerenciamento de casos pendentes perante o Poder Judiciário. Constatando-se a recorrente existência de centenas ou milhares de casos com pretensão idêntica, o Poder Judiciário brasileiro produziria uma decisão que valeria, uniformemente, para todos eles. Assim, ressalvada a ocorrência de peculiaridades específicas, que demandariam exame mais acurado do caso, seria possível que essa decisão paradigma fosse praticamente reproduzida, facilitando a resolução dos casos repetitivos.

Esse cenário, que pode parecer estranho, é, em realidade, compreensível. Como o acesso à justiça é amplo e barato, o surgimento de uma tese jurídica nova acarreta, em curto prazo, o ajuizamento de milhares de ações novas. Como o processo é lento, a definição acerca de essa tese ser ou não acertada demora significativamente. Enquanto isso não ocorre, mais ações são propostas, já que o risco, em caso de derrota, é baixo. A discordância entre os juízes, acerca do acerto da tese dos autores, amplia o fomento à propositura de novas ações, já que o risco é baixo. Quando o

10 Esse problema atingiu tal proporção que, depois de aprovado e sancionado o texto, parte dele foi alterado por outra lei, antes mesmo de entrar em vigor, como forma de reduzir a insatisfação dos juízes. 
precedente judicial é, finalmente, estabelecido, ele incide sobre milhares de casos pendentes e se transforma, naturalmente, em um mecanismo de gestão do estoque processual, antes de ser uma definição sobre a norma jurídica válida para o caso.

A constatação exposta se confirma, quando se percebe que o Código brasileiro não transformou todas as decisões dos tribunais em precedentes obrigatórios. Pelo contrário, elegeu algumas espécies de procedimento, que exigem deliberações de maiorias qualificadas, para produzir precedentes. As demais decisões dos tribunais permanecem meramente persuasivas para os juízos inferiores. Dentre os seis mecanismos processuais de produção de precedentes obrigatórios, estabelecidos pelo Código de Processo Civil de 2015"11, três exigem a "efetiva repetição de processos" (art. 976, CPC/15, incidente de resolução de demandas repetitivas - IRDR); a "multiplicidade de recursos extraordinários ou especiais com fundamento em idêntica questão de direito" (art. 1.035, CPC/15 - RE/REsp repetitivos), ou as "reiteradas decisões sobre matéria constitucional" (art. 103-A, Constituição, súmula vinculante - SV).

Em outras palavras, o legislador brasileiro, temeroso de realizar uma guinada brusca no rumo do Common Law, não considerou todas as decisões dos tribunais - nem mesmo do Supremo Tribunal Federal -como precedentes vinculantes. A obrigatoriedade deriva do procedimento de produção da decisão, que tem que se amoldar a uma das hipóteses previstas em lei, as quais exigem, para a formação do precedente vinculante, a reiteração ou a repetição de casos. Assim, por exemplo, quando a Suprema Corte dos Estados Unidos julgou o caso Brown v. Board of Education, em 1954, sua preocupação era tomar uma decisão que fosse capaz de considerar a segregação ilegal em todo o sistema educacional do país. Quando o Supremo Tribunal Federal brasileiro julgou, em 2016, a impossibilidade de se refazer o cálculo dos valores devidos a pessoas já aposentadas (chamada de "desaposentação"), o fez com o propósito de resolver mais de 400 mil processos já em andamento.

Ainda é cedo para dizer de que forma o sistema brasileiro de precedentes vinculantes se desenvolverá. O certo é que ele nasce com a marca de um mecanismo de gerenciamento de demanda processual, não com o objetivo de criar normas jurídicas que contribuam para a integridade do ordenamento jurídico. Os órgãos jurisdicionais superiores não estão preocupados, como propõe Perelman ${ }^{12}$, com a pacificação judiciária e com a produção de decisões cujas respectivas razões sejam capazes de convencer as cortes inferiores e a sociedade quanto ao seu acerto. A questão é baixar o estoque de processos, "clean the docket". É, como em um naufrágio, retirar a maior quantidade de água possível do casco do navio, antes que mais líquido venha a entrar.

11 Cinco desses mecanismos estão previstos no art. 927 do CPC. São eles: 1) julgamentos do STF em ações diretas de inconstitucionalidade; 2) súmulas vinculantes aprovadas pelo STF; 3) julgamentos de casos repetitivos pelo STF, STJ ou tribunais de apelação; 4) súmulas do STF ou do STJ; 5) decisões de plenário dos tribunais. O sexto mecanismo está previsto no art. 1.035 do CPC e consiste nas decisões do STF em julgamento de recursos extraordinários com repercussão geral.

12 PERELMAN, C. Ética e direito. Tradução de Maria Ermantina de Almeida Prado Galvão, 2. ed. São Paulo: Martins Fontes, 2005. p. 566. 


\section{A TECNOLOGIA HÁ DE NOS SALVAR: FERRAMENTAS DE INTELIGÊNCIA ARTIFICIAL}

A segunda inovação significativa no sistema jurídico brasileiro, que, coincidentemente, surgiu ao mesmo tempo que o CPC/15, foi a adoção pelos tribunais de ferramentas tecnológicas e de inteligência artificial. A liderança desse movimento coube ao próprio Supremo Tribunal Federal que, em parceria com a Universidade de Brasília (UnB), desenvolveu o Projeto Victor. No anúncio de seu lançamento, o site oficial do STF justificou o projeto, noticiando que ele "utiliza Inteligência Artificial (IA) para aumentar a eficiência e a velocidade de avaliação judicial dos processos que chegam ao tribunal. com o objetivo de avaliar os recursos recebidos"13 e que, por esse motivo, de acordo com a então Presidente do Tribunal, Ministra Cármen Lúcia, "a ferramenta possibilitará melhor aproveitamento de recursos materiais e humanos do Tribunal, acelerando a análise dos processos e reduzindo o congestionamento na admissibilidade dos recursos nos tribunais de origem"14.

Resta claro que o objetivo principal da proposta de desenvolvimento tecnológico, apresentada pela Suprema Corte, é evitar que a análise dos recursos que a ela são dirigidos seja feita "case by case", substituindo-a por uma avaliação massificada, conduzida por inteligência artificial, que, muitas vezes apresenta mais fracassos do que efetivamente sucessos. ${ }^{15} \mathrm{~A}$ preocupação, mais uma vez, não é com a qualidade, mas com a quantidade de trabalho. A eficiência é retratada, no próprio discurso oficial do tribunal, como redução de custos, uso de mão de obra e prazos, não como a produção de decisões mais qualificadas nos importantes temas que lhe são submetidos. ${ }^{16}$

Em sentido similar, o Tribunal de Justiça de Minas Gerais criou um projeto de inteligência artificial denominado Radar. Na primeira vez em que ele foi utilizado, o intuito, conforme divulgado pelo próprio tribunal, foi o de identificar 280 (duzentos e oitenta) casos similares e julgá-los "com apenas um click [...], em menos de um segundo"17. Para o Vice-Presidente do Tribunal, essa foi "uma das sessões mais importante do Poder Judiciário de todos os tempos. Trata-se de um grande salto em direção ao futuro"18.

Como se percebe, a partir dessa análise discursiva, a incorporação de ferramentas de tecnologia e inteligência artificial no direito brasileiro não se faz com o propósito de ampliar o espectro de informações disponíveis para a tomada de decisão, nem de melhorar a qualidade do trabalho dos

13 BRASIL. Supremo Tribunal Federal. Disponível em: http://www.stf.jus.br/portal/cms/verNoticiaDetalhe. asp?idConteudo=388443. Acesso em: 15 maio 2019.

14 BRASIL. Supremo Tribunal Federal. Disponível em: http://www.stf.jus.br/portal/cms/verNoticiaDetalhe. asp?idConteudo=388443. Acesso em: 15 maio 2019.

15 Ver também em DREYFUS, H. L. e DREYFUS, S. E. Mind over machine: The power of human intuition Expertise in the era of the computer. New York, Free Press. 1986.

16 Ver também em CHABLO, A. What can artificial intelligence do for Anthropology? Current Anthropology.v. 37, p. 553-555, 1996.

17 Ver também em BRASIL. Tribunal de Justiça de Minas Gerais. Disponível em: https://www.tjmg.jus.br/portal-tjmg/ noticias/tjmg-utiliza-inteligencia-artificial-em-julgamento-virtual.htm. Acesso em: 20 maio 2019.

18 Ver também em BRASIL. Tribunal de Justiça de Minas Gerais. Disponível em: https://www.tjmg.jus.br/portal-tjmg/ noticias/tjmg-utiliza-inteligencia-artificial-em-julgamento-virtual.htm. Acesso em: 20 maio 2019. 
juízes. ${ }^{19}$ Em outras palavras, a tecnologia não tem sido buscada como uma ferramenta para auxiliar qualitativamente a tomada de decisão, mas tão somente para resolver o maior número de casos, no menor tempo possível. Em vez de a inteligência artificial se colocar como "coadjuvante de infungíveis habilidades e virtudes humanas"20, ela se torna apenas um mecanismo para produzir decisões de forma mais rápida e barata, mas não necessariamente melhores.

\section{HIPÓTESE: TECNOLOGIA E PRECEDENTES PODEM ELEVAR A PROPENSÃO A JULGAMENTOS DE IMPROCEDÊNCIA}

Nos últimos tempos, os estudos de psicologia cognitiva aplicados ao Direito têm demonstrado que os critérios de tomada de decisão, inclusive os de decisão judicial, não são puramente objetivos. Como qualquer tomada de decisão implica a seleção de inputs relevantes ou irrelevantes para o caso, ela pode ser influenciada por fatores externos e inconscientes, que incidem sobre os juízes em virtude da sua condição humana. Tais fatores incluem erros e vieses cognitivos (cognitive biases), que podem fazer com que a decisão não corresponda apenas aos fatores que o magistrado conscientemente pondera ${ }^{21}$.

Esta pesquisa levanta a hipótese de que, em um sistema processual quantitativamente sobrecarregado, a introdução de precedentes obrigatórios e de ferramentas tecnológicas pode ser apropriada por uma ideologia de agilidade e eficiência na prestação jurisdicional, que se preocupa mais com a quantidade do que com a qualidade das decisões. Até aí, não haveria muito problema. Como se costuma dizer no Brasil, "justiça que tarda é justiça que falha". Acelerar a justiça é, portanto, um bem. O problema é que parece que a junção de um sistema de precedentes com ferramentas tecnológicas pode acarretar um viés cognitivo que induza os juízes a tomar decisões de improcedência dos pedidos apresentados repetitivamente à justiça. Isso porque os tribunais, ao implementarem ferramentas tecnológicas capazes de identificar quais são os casos mais numerosos e, ao serem capazes de produzir uma decisão obrigatória, válida para todos esses casos, podem ser levados, ainda que inconscientemente, a um raciocínio quantitativo, de gestão de acervo. Esse raciocínio se apresentaria da seguinte forma: "se eu conceder esse direito às pessoas que o estão requerendo, receberei, amanhã, milhares de outros pedidos idênticos, além dos muitos que já tenho. Se, por outro lado, eu negar o direito, não apenas resolvo os casos pendentes, mas também inibo a propositura de muitos outros".

Ressalte-se, mais uma vez, que esse raciocínio não precisa acontecer de modo consciente. Conforme demonstrado, o julgador brasileiro é cotidianamente confrontado com notícias e estatísticas oficiais acerca da lentidão do sistema, da sua sobrecarga e da tarefa impossível com a qual ele se defronta. O Conselho Nacional de Justiça (CNJ) produz um relatório anual sobre as estatísticas da justiça, no qual ressalta o número de processos recebidos, a produtividade dos juízes e a demora na

19 Ver também em BALDI, S. Normative versus Social Constructivist Processes in the Allocation of Citations: A network-analytic model. American Sociological Review, Vol. 63, p. 829-846, 1998 e ZAMIR, E.; TEICHMAN D. Behavioral Law and Economics. London: Oxford University Press, 2018.

20 FREITAS, J. Direito Administrativo e inteligência artificial. Interesse Público - IP, Belo Horizonte, ano 21, n. 114, p. 15 - 29, mar./abr. 2019. p. 15.

21 Ver, entre vários estudos, TVERSKY, A.; KAHNEMAN, D. Availability: A heuristic for judging frequency and probability. In: Cognitive Psychology, v. 2, n. 5, 1973. p. 207. 
prolação da sentença e no cumprimento da decisão. Muito pouco se escreve sobre a qualidade das decisões produzidas. Assim, a percepção do juiz é sensibilizada de tal forma para esses problemas estruturais quantitativos que parece razoável supor que, confrontado com um caso capaz de gerar milhares de processos, o julgador poderia ser levado a dar mais valor aos elementos que indicam a improcedência do pedido, a qual é capaz de reduzir o potencial para novas demandas. Por outro lado, os fatores que indicam a procedência do pedido podem ser inconscientemente vistos com ressalvas, dado o seu potencial para aumentar a demanda.

Para testar essa hipótese, realizou-se uma análise quantitativa e qualitativa de uma amostra de precedentes vinculantes, colhidos de alguns tribunais brasileiros. Os resultados são apresentados a seguir. É bom ressaltar que, embora esta pesquisa enfoque a situação do Poder Judiciário brasileiro, os resultados aqui mostrados são extrapoláveis para outros países em situações semelhantes. A discussão acerca da sobrecarga judicial não é exclusiva do Brasi|22.

\section{ANÁLISE EMPÍRICA QUANTITATIVA DOS PRECEDENTES VINCULANTES DE TRIBUNAIS BRASILEIROS}

Conforme relatado, adotar ou não um precedente vinculante é, em alguma medida, uma decisão discricionária dos tribunais brasileiros. Como nem todas as decisões judiciais são obrigatórias, e a escolha das teses que vão ser submetidas ao procedimento de formação de precedentes é, em alguma medida, subjetiva, os tribunais são capazes de optar por formar ou não um precedente. Assim, analisar quais precedentes foram formados nos últimos anos, por esses tribunais, pode indicar os propósitos que o sistema tem cumprido.

Para uniformização da nomenclatura, foram denominadas teses multiplicativas, as decisões que favorecem a parte do conflito que está em maior número e que, por essa razão, se a tese for vencedora e formar o precedente, fomentará a propositura de novas ações. São teses, portanto, favoráveis aos autores das ações judiciais. De outro lado, chamou-se de teses restritivas, aquelas que têm o potencial para limitar o interesse em litigar, favorecendo, assim, os réus. Logo, a hipótese se confirmará se for encontrado um número significativo de teses restritivas, em detrimento de teses multiplicativas. Quando a tese não tem potencial nem para restringir, nem para multiplicar o número de processos relativos à controvérsia, ela foi reputada irrelevante para os fins desta pesquisa e, então, descartada. Cabe mencionar que o juízo sobre uma tese ser multiplicativa ou restritiva foi feito pelos autores e, por isso, está sujeito a alguma margem de subjetividade e erro.

É bom observar também que as pessoas que são beneficiadas pelas teses multiplicativas ou restritivas não são, em absoluto, as mesmas, nem é aleatório o seu posicionamento. Como observou

22 Sobre o assunto, ver o estudo comparativo de ROUSSEY, L.; SOUBEYRAN, R. Overburdened Judges. International Review of Law and Economics, v. 55, September 2018. p. 21-32. Tratando do caso indiano, em que pendem 30 milhões de processos (menos da metade do Brasil). 
Novos Estudos Jurídicos

Galanter ${ }^{23}$, o desequilíbrio de forças que se verifica entre grupos dominantes e grupos vulneráveis, na sociedade, se reproduz amplamente no processo. Assim, as teses multiplicativas favorecem, em regra, consumidores, trabalhadores, vítimas de acidentes ambientais, grupos minoritários e desfavorecidos. As teses restritivas favorecem o próprio Estado que, no Brasil, é um dos maiores litigantes, bem como o grande capital, formado por bancos, pelos setores produtivos de modo geral, o empresariado etc.

Isso se deve ao fato de que o fenômeno da multiplicação processual decorre, em regra, de um dano causado a partir de um centro singular, que se espalha para atingir várias pessoas ${ }^{24}$. Isso permite ao causador do dano a realização de um cálculo econômico para avaliar o custo que teria para evitar o dano e aquele que deriva do processo. Esse sujeito, por isso, externaliza os custos da sua atividade econômica para a sociedade, que é vítima dos ilícitos, e para o sistema de justiça, que precisa processar o caso. Assim, o predomínio das teses restritivas sobre as teses multiplicativas é um indício de que o sistema tenderá a favorecer os grupos socialmente dominantes, em detrimento dos grupos mais vulneráveis.

No Superior Tribunal de Justiça, optou-se por alguns temas que usualmente geram causas repetitivas e foram verificadas apenas as decisões que foram tomadas pelo tribunal com a utilização de uma técnica para produzir precedentes obrigatórios. Classificando essas decisões de acordo com o seu perfil multiplicativo ou restritivo, encontrou-se o seguinte cenário, retratado no Quadro 1.

Quadro $7^{25}$

\begin{tabular}{|c|c|c|c|}
\hline $\begin{array}{c}\text { Tema tratado no } \\
\text { processo }\end{array}$ & $\begin{array}{c}\text { Decisões } \\
\text { multiplicativas }\end{array}$ & Decisões restritivas & $\begin{array}{c}\text { Índice de } \\
\text { vitória das teses } \\
\text { multiplicativas }\end{array}$ \\
\hline Direito Bancário & 06 & 08 & $42,86 \%$ \\
\hline Servidores Públicos & 02 & 05 & $28,57 \%$ \\
\hline $\begin{array}{c}\text { Direito do } \\
\text { consumidor }\end{array}$ & 05 & 10 & $33,33 \%$ \\
\hline $\begin{array}{c}\text { Direito } \\
\text { previdenciário }\end{array}$ & 10 & 07 & $58,82 \%$ \\
\hline
\end{tabular}

23 GALANTER, M. Why the "haves" come out ahead: speculations on the limits of legal change. 9 Law \& Soc'y Rev., v. 95, 1974-1975. p. 95.

24 Essa irradiação de efeitos pode ocorrer de maneiras distintas e, com isso, implicar perfis diferentes de litígios. Cabe observar que, embora o sistema permita que esses casos sejam processados individualmente, o litígio é, em realidade, coletivo, uma vez que a sociedade é lesada como grupo, independentemente das características dos indivíduos envolvidos. Sobre os perfis de litígio coletivo ver em VITORELLI, E. O devido processo legal coletivo: dos direitos aos litígios coletivos. São Paulo: RT, 2016 e, de modo mais sucinto, mas em inglês, VITORELLI, E.. Collective Due Process of Law: Reconciling Representation and Participation. In: Cadiet, L.; Hess, B.; Requejo Isidro, M.. (org.). Approaches to Procedural Law The Pluralism of Methods. 1. ed. Baden-Baden, Germany: Nomos, 2017, v. 1, p. 345-391.

25 SUPERIOR TRIBUNAL DE JUSTIÇA. Banco de teses do Superior Tribunal de Justiça. Disponível em: http://www. stj.jus.br/repetitivos/temas_repetitivos/. Acesso em: 20 ago. 2020. 
A análise qualitativa de alguns precedentes específicos, que compõem a amostra quantitativamente classificada no Quadro 1, revela que a situação é ainda pior. Por exemplo, duas teses de direito do consumidor que foram consideradas multiplicativas têm relação apenas com a legitimidade para processar e com o prazo prescricional ${ }^{26}$, não com o mérito, ou seja, com o fato de o consumidor ter ou não razão. Uma dessas teses foi, no mérito, negada pelo STJ, no tema $939^{27}$. Nesse cenário, a despeito de o consumidor ter possibilidade de processar, no mérito, ele vai perder. Logo, a decisão favorável ao consumidor, que poderia ser multiplicativa, deixa de ter utilidade.

Quando se agregam todas as decisões analisadas, independentemente do tema, as teses multiplicativas prevalecem, na média geral, em apenas 37\% dos casos, enquanto as teses restritivas atingem 63\% das decisões. No âmbito do Superior Tribunal de Justiça, encarregado de uniformizar, em caráter definitivo, a interpretação das leis federais, há indícios de que as teses restritivas sejam preferidas.

Esse exame puramente quantitativo ainda esconde os efeitos da importância relativa de cada um dos casos. Por exemplo, o STJ negou aos consumidores o direito de não pagar a assinatura básica do serviço de telefonia, eliminando, em uma única decisão, a possibilidade de que as empresas de telefonia perdessem uma receita equivalente a R \$ 13 bilhões (US\$ 3,5 bilhões) por ano. Nessa decisão, o voto vencido do Ministro Herman Benjamin fez duras críticas ao modo como a causa foi processada, com ampla mobilização das empresas, em detrimento dos consumidores:

[...] elegeu-se exatamente a demanda de uma consumidora pobre e negra (como dissemos acima, triplamente vulnerável), destituída de recursos financeiros para se fazer presente fisicamente no STJ, por meio de apresentação de memoriais, audiências com os Ministros e sustentação oral. [...] Como juiz, mas também como cidadão, não posso deixar de lamentar que, na argumentação(?) oral perante a Seção e também em visitas aos Gabinetes, verdadeiro monólogo dos maiores e melhores escritórios de advocacia do País, a voz dos consumidores não se tenha feito ouvir. [...] Em síntese, a vitória das empresas de telefonia, que hoje se prenuncia, não é exclusivamente de mérito; é, antes de tudo, o sucesso de uma estratégia judicial, legal na forma, mas que, na substância, arranha o precioso princípio do acesso à justiça, uma vez que, intencionalmente ou não, inviabiliza o debate judicial e o efetivo contraditório. ${ }^{28}$

26 É o caso dos temas de recursos repetitivos 449 e 938 . O primeiro trata de prazo decadencial para o consumidor bancário; e o segundo, de legitimidade do consumidor para processar construtoras.

27 SUPERIOR TRIBUNAL DE JUSTIÇA. Tema 939, Discute-se a legitimidade passiva da incorporadora (promitente vendedora) para responder pela restituição da comissão de corretagem e da taxa de serviço de assessoria técnicoimobiliária (SATI), sob o fundamento da abusividade da transferência desses encargos ao consumidor. Disponível em:http://www.stj.jus.br/repetitivos/temas_repetitivos/pesquisa.jsp?novaConsulta=true\&tipo_pesquisa=T\&sg_ classe=REsp\&num_processo_classe=1551951. Acesso em: 20 ago. 2020.

28 BRASIL. Superior Tribunal de Justiça. REsp 911.802/RS, Rel. Ministro JOSÉ DELGADO, PRIMEIRA SEÇÃO, julgado em 24/10/2007, DJe 01/09/2008. 
Essa crítica apenas concretiza a percepção teórica de David Rosenberg ${ }^{29}$, no sentido de que o sistema de justiça individual assegura aos réus de processos coletivos o benefício de economia de escala que nega aos autores. Para o réu, existe sempre uma ação coletiva de fato, eis que ele pode diluir seus custos processuais entre todos os processos e ainda externalizar parte deles para o sistema de justiça. Existe a possibilidade de tratar todos os casos como se fossem apenas um. Ele contrata o mesmo escritório de advocacia, elabora a mesma defesa, investe na produção da prova técnica e ainda pode repassar seus custos aos próprios lesados, dependendo das condições do mercado em que atua, revertendo o prejuízo em aumento de preços. Assim, quanto maior for o número de causas, menor será o seu custo individual para o litigante habitual. Pelo contrário, os autores têm que contratar advogados e preparar suas ações individualmente, o que os coloca em uma posição de menor eficiência, que pode chegar ao limite do desinteresse econômico. O autor isolado, que litiga uma única causa, não tem estímulos racionais para nela investir mais do que o valor do direito que tem, individualmente, em jogo, ainda que a tese, coletivamente, valha mais para a sociedade. Nesse contexto, não há como descartar a hipótese de que o predomínio das decisões restritivas derive não apenas de um viés cognitivo decorrente da percepção de sobrecarga judicial, mas também da maior mobilização dos beneficiários de tais decisões, que têm interesse em investir mais nos casos em que estão envolvidos.

Além da pesquisa no Superior Tribunal de Justiça, foram investigados dois tribunais de apelação, os quais puderam produzir precedentes obrigatórios apenas a partir de 2016. No Tribunal de Justiça do Rio Grande do Sul e de Goiás, sem controlar pelo assunto do precedente - já que os casos são menos numerosos - encontraram-se os seguintes dados, tomando como base o Incidente de Resolução de Demandas Repetitivas (IRDR), conforme sintetiza o Quadro 2:

\section{Quadro $2^{30}$}

\begin{tabular}{|c|c|c|c|}
\hline Estado do Tribunal & $\begin{array}{c}\text { Decisões } \\
\text { multiplicativas }\end{array}$ & $\begin{array}{c}\text { Decisões } \\
\text { restritivas }\end{array}$ & $\begin{array}{c}\text { Índice de } \\
\text { vitória das teses } \\
\text { multiplicativas }\end{array}$ \\
\hline Rio Grande do Sul & 01 & 05 & $16,6 \%$ \\
\hline Goiás & 02 & 02 & $50 \%$ \\
\hline
\end{tabular}

Como se observa, o predomínio de teses restritivas nos tribunais de apelação é ainda maior que no Superior Tribunal de Justiça. Embora o número de decisões seja pequeno, o que reduz a confiabilidade da análise quantitativa, parece que a recente experiência dos tribunais de justiça com precedentes obrigatórios caminha para uma tendência de restrição de direitos.

29 ROSENBERG, D. Mass tort class actions: what defendants have and plaintiffs don't. Harvard Journal on legislation, v. 37, p. 393-431, 2000. p. 393.

30 TRIBUNAL DE JUSTIÇA DO RIO GRANDE DO SUL. Núcleo de Gerenciamento de Precedentes. Disponível em: https://www.tjrs.jus.br/novo/institucional/2o-grau/nugep/. Acesso em: 20 ago. 2020. TRIBUNAL DE JUSTIÇA DE GOIÁS. Núcleo de Gerenciamento de Precedentes. Disponível em: https://www.tjgo.jus.br/index.php/nucleo-degerenciamento-de-precedentes-nugep/recursos-repetitivos. Acesso em: 20 ago. 2020. 
O desenvolvimento da tecnologia tende a ampliar essa distância e, com isso, aumentar as chances de que as teses restritivas prevaleçam. Ferramentas de inteligência artificial e análise de big data podem ser utilizadas não apenas pelo Poder Judiciário, como já foi narrado, mas também pelos réus, para identificar as teses mais fortes e mais fracas, permitindo que sejam celebrados acordos nas primeiras, enquanto as últimas são levadas adiante, para produzir precedentes vinculantes interessantes para o réu. Enquanto isso, os autores continuarão litigando de modo artesanal e individual, já que não teriam estímulos para aportar o capital necessário para a aquisição dessas ferramentas.

Além disso, a adoção da tecnologia pelo Poder Judiciário sempre poderá ser questionada pelo réu, que pode contratar peritos para estudar os algoritmos e as ferramentas de inteligência artificial utilizados. Os autores, mais uma vez, em isolamento, serão conduzidos pelo sistema na confiança da sua neutralidade, o que já foi muitas vezes questionado. Não há nenhuma garantia de que os algoritmos adotados pelo Poder Judiciário sejam neutros e, se não forem, é certo que o réu terá mais ferramentas para detectar o problema do que os autores.

Esses problemas qualitativos do uso da tecnologia, como é o caso da neutralidade, passam ao largo da discussão em um sistema jurisdicional altamente sobrecarregado. Sua prioridade, expressa em entrevistas de julgadores, já citadas, é a identificação do maior número possível de casos que possam ser julgados no menor tempo, «com um click».

\section{ANÁLISE EMPÍRICA QUALITATIVA: OUTRAS TÉCNICAS RESTRITIVAS DE DEMANDA NO CONTEXTO DE DECISÕES JUDICIAIS OBRIGATÓRIAS}

Além da análise quantitativa, procede-se, nos tribunais de apelação, uma análise qualitativa de três casos de grande repercussão, para observar outra maneira como o sistema de precedentes obrigatórios pode ser utilizado para restringir a multiplicação de processos.

Dois dos casos analisados se referem à formação rápida de um precedente obrigatório, contrário às pretensões dos autores, o que acarreta restrição de demanda. Em ambos os casos foi possível notar, por intermédio de exame qualitativo, a formação apressada de precedentes, em um momento em que o debate ainda ocorria predominantemente em $1 .^{\circ}$ grau. Ao julgar a tese ainda imatura e adotar uma posição restritiva, o tribunal tem a possibilidade de reduzir o seu potencial de multiplicação.

O Tribunal de Justiça de São Paulo julgou o IRDR 20, para negar ao consumidor o direito de reivindicar redução em sua conta de esgoto. Embora a lei exija a repetição de casos e o risco à isonomia e à segurança jurídica para a tramitação do IRDR, o TJ-SP identificou apenas 18 casos com a mesma tese que foi julgada e rechaçada. Se, no entanto, a tese tivesse sido acolhida, o tribunal estaria exposto a 7,4 milhões de novas ações, número total de clientes da Companhia Estadual de Saneamento. O precedente restritivo, afirmando a legalidade da cobrança, bloqueou o crescimento 
da tese. De modo similar, o Tribunal de Justiça do Rio de Janeiro admitiu um IRDR para firmar posicionamento quanto à possibilidade de que o Estado seja condenado a indenizar seus servidores em virtude do atraso no pagamento de suas respectivas remunerações. $O$ atraso se deve a uma forte crise financeira pela qual passa o Estado e foi fundado em uma autorização em lei estadual. O incidente foi o primeiro a ser admitido pelo TJ-RJ (IRDR n. ${ }^{\circ}$ ), apenas cinco meses depois da edição de normas que autorizaram o Estado a pagar em atraso.

No momento em que a discussão do precedente foi iniciada, sequer havia uma causa pendente de julgamento sobre o tema perante o TJ-RJ. O incidente foi instaurado em abstrato, apenas pela informação da existência da controvérsia em $1 .^{\circ}$ grau $^{31}$. A possibilidade de se firmar um precedente dessa forma é altamente controversa no pensamento jurídico nacional. Apesar disso, o Tribunal determinou a suspensão de todos os processos em andamento e, com isso, desestimulou a propositura de novas ações. A suspensão completou quatro anos em maio de 2020, sem que o caso tenha sido julgado, embora o CPC disponha expressamente que o julgamento deveria ocorrer em um ano (art. 980).

O terceiro caso vem do IRDR 40, instaurado pelo Tribunal de Justiça do estado do Espírito Santo, também em 2016. Nele, o tribunal tratou da situação das vítimas do desastre ambiental do Rio Doce. Em razão da contaminação do rio, essas pessoas foram totalmente privadas do abastecimento de água potável por um período de 08 a 12 dias. O Tribunal firmou precedente obrigatório no sentido de que elas deveriam receber R\$ 1 mil (US\$250) como indenização.

Embora a decisão pareça favorável às vítimas ela é, na realidade, altamente desfavorável e pautada pelo controle de demanda processual. No momento em que o IRDR foi instaurado, estimava-se que pendiam aproximadamente 100 mil ações judiciais com esse objeto. O resultado oculto da decisão é que o valor estabelecido pelo TJ-ES é praticamente o mesmo que estava sendo oferecido extrajudicialmente às vítimas, pelas empresas causadoras do dano ${ }^{32}$. $\mathrm{A}$ mensagem ficou muito clara: quem ingressar judicialmente não vai ganhar mais do que aquele que aceitar um acordo.

Além de discutível, esse método de impelir as partes ao acordo tem um grave defeito de conteúdo: o valor oferecido é irrisório, quando comparado à dimensão do dano. As vítimas ficaram mais de uma semana sem água potável em casa e receberiam apenas $\mathrm{R} \$ 1$ mil. O Superior Tribunal de Justiça, por outro lado, considera adequada a indenização de R\$ 4 mil (US\$ 1 mil) por um (simples)

31 O incidente foi instaurado na ação 0135325-80.2016.8.19.0001, que ainda tramita em $1 .^{\circ}$ grau, na $5 .^{a}$ Vara de Fazenda Pública do Rio de Janeiro.

32 A Fundação Renova, instituição criada com a finalidade específica de promover as reparações de danos decorrentes do desastre de Mariana, celebrou a adesão de pouco mais de 250 mil vítimas ao programa, sem mencionar o problema destacado no texto. Ver https://www.fundacaorenova.org/noticia/programa-de-indenizacaomediada-para-dano-agua-encerra-com-98-de-adesao/. Acesso em 14.9.20 


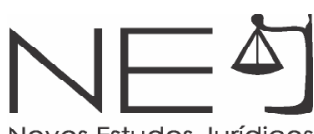

atraso de voo ${ }^{33}$. Assim, o precedente, além de desestimular o ajuizamento de novas ações, ainda serve para estabelecer um patamar de reparação atipicamente baixo, mesmo para o contexto nacional, que não admite danos punitivos.

A análise qualitativa efetuada aqui se complementa por um silêncio eloquente. Se o que se quer é inibir a demanda judicial pela adoção de uma decisão que fomente as partes a buscar outro resultado, seria possível fazê-lo também de outra forma. Bastava formar, rapidamente, um precedente que impusesse ao réu uma pesada condenação. Isso o estimularia a fazer tentativas significativas de obter acordos, antes que mais pessoas pudessem pleitear seus direitos em juízo. No entanto, não foi possível, na pesquisa, encontrar um caso em que o sistema de precedentes tenha sido utilizado para formar, rapidamente, um precedente que impusesse ao réu derrota significativa. Mesmo quando as pessoas lesadas são vitoriosas, as indenizações costumam ser baixas em relação ao dano causado e/ou levar muitos anos para serem definidas. No caso dos expurgos inflacionários dos planos econômicos, por exemplo, o acordo só foi celebrado mais de 30 anos depois do dano causado ${ }^{34}$.

Há, portanto, evidências empíricas de um descompasso entre os estímulos racionais que são oferecidos aos autores e aos réus pelo sistema processual brasileiro. Para os autores, a mensagem que se passa é a de não judicialização, a de obtenção de um acordo, mesmo que por baixo valor, extrajudicialmente, ou, pior ainda, a negativa de direitos. Para os réus, esse mesmo comportamento judicial tem potencial para estimular o comportamento irresponsável, a pouca disposição para chegar a acordos, a sensação de impunidade e, com isso, o estímulo para cometer mais atos ilícitos.

Com isso, ironicamente, os números de processos tendem a voltar a subir, chegando ao resultado oposto ao que se pretendia obter com a formação do precedente.

\section{CONSIDERAÇÕES FINAIS}

Em conclusão, observa-se que, embora haja necessidade de pesquisas empíricas mais minuciosas, há evidências, tanto quantitativas quanto qualitativas, no sentido de que a introdução de precedentes obrigatórios e de ferramentas tecnológicas, em um sistema processual altamente sobrecarregado, pode induzir vieses cognitivos em favor da improcedência dos pedidos que tenham potencial multiplicativo.

33 Aglnt no REsp 1264639/RJ, Rel. Ministro RAUL ARAÚJO, QUARTA TURMA, julgado em 26/03/2019, DJe 11/04/2019. Não se pode dizer, no entanto, que a vítima do atraso de voo tenha tido, no Poder Judiciário brasileiro, um destino melhor que o narrado no texto. A ação de indenização foi iniciada em 2011, e o caso só foi julgado pelo STJ em 2019, para garantir a quantia que, embora razoável, nem de longe justifica oito anos de atividade judicial. Quando o processo acabou, a companhia aérea (Varig) já havia falido e sido comprada por outra empresa. Não há notícia se o valor foi efetivamente pago.

34 VITORELLI, E. Acordo coletivo dos planos econômicos e por que ele não deveria ser homologado. Disponível em: https://www.jota.info/paywall?redirect_to=//www.jota.info/opiniao-e-analise/artigos/acordo-coletivodos-planos-economicos-e-por-que-ele-nao-deveria-ser-homologado-15012018. Acesso em: 21 maio 2019. 
Do ponto de vista quantitativo, encontra-se, em todos os tribunais pesquisados, prevalência, por vezes significativa, de precedentes obrigatórios restritivos em relação a teses que teriam potencial para se multiplicar. Essa tendência não seria de se esperar, visto que a própria natureza numerosa dos casos significa que muitos advogados consideraram a tese fundada o bastante para apresentá-la em juízo. Essa tendência é indicativa de que as decisões dos tribunais podem estar considerando não apenas o mérito do caso em si, mas também o seu potencial para gerar novos processos.

Do ponto de vista qualitativo, analisaram-se casos em que o modo como o precedente foi formado serviu para desestimular o ajuizamento de novas ações, seja pela agilidade da sua formação, com conteúdo contrário ao interesse dos autores, pela imposição de suspensão de ações em andamento seja pela definição de patamares indenizatórios similares aos que o réu já oferecia extrajudicialmente. De outro lado, não se encontrou caso algum em que a formação do precedente, em desfavor do réu, tenha ocorrido com agilidade e rigor suficientes para fomentar acordos.

Em relação às inovações tecnológicas, catalogaram-se notícias oficiais de tribunais, nas quais esses desenvolvimentos, sobretudo relacionados às ferramentas de inteligência artificial, são apontados como método de se decidir não o melhor, mas apenas mais rapidamente. Também se ressalta que o monitoramento estatístico, realizado pelo Conselho Nacional de Justiça, por intermédio de aparatos tecnológicos, enfoca exclusivamente o aspecto quantitativo da atuação jurisdicional, sem qualquer referência qualitativa.

Nesse contexto, as evidências indicam que, em sistemas processuais sobrecarregados, a introdução de recursos tecnológicos e de precedentes obrigatórios tende a fomentar, pela via de vieses cognitivos (isto é, inconscientemente), decisões judiciais de improcedência, as quais passam a funcionar como instrumento de controle da demanda judicial. Nesse sentido, os levantamentos realizados indicam a confirmação da hipótese inicial.

Essa constatação denota que os tribunais e os órgãos gestores do Poder Judiciário, em qualquer país com sobrecarga quantitativa de processos, deveriam proceder com cautela na utilização de instrumentos tecnológicos, na introdução de precedentes obrigatórios e na reiteração de discursos que enfoquem apenas o aspecto da agilidade e da eficiência na prestação jurisdicional. A gestão do acervo judiciário não deveria ser causa de negativa dos direitos das partes, sobretudo porque as situações com potencial multiplicativo são protagonizadas, em regra, por pessoas vulneráveis. Quando se analisa quem ganha e quem perde, nesse cenário, não pode haver margem para ingenuidade.

\section{REFERÊNCIAS DAS FONTES CITADAS}

ALMEIDA, W. G. R. de. Direito Processual Metaindividual do Trabalho: a adequada e efetiva tutela jurisdicional dos direitos de dimensão transindividual. Salvador: Editora JusPODIVM, 2016.

ALTMAN, M. (org.). Real-World Decision Making: An Encyclopedia of Behavioral Economics. Santa Barbara: Greenwood, 2015. 
BALDI, S. Normative versus Social Constructivist Processes in the Allocation of Citations: A networkanalytic model. American Sociological Review. v. 63. p. 829-846. 1998.

BRASIL. Superior Tribunal de Justiça. REsp 911.802/RS, Rel. Ministro JOSÉ DELGADO, PRIMEIRA SEÇÃO, julgado em 24/10/2007, DJe 01/09/2008.

BRASIL. Tribunal de Justiça do Estado de São Paulo; Processo Paradigma: IRDR Nº 0043917-79.2017.8.26.0000; Assunto: DIREITO CIVIL - Obrigações - Espécies de Contratos - Prestação de Serviços; Órgão Julgador: Turma Especial de Direito Privado; NUT: 8.26.1.000020; Relator(a): Desembargador GOMES VARJÃO; Data de Admissão: 25/06/2018; Data de Publicação do Acórdão de Admissibilidade: 12/07/2018; Data de Mérito Julgado: 15/10/2018; Data de Publicação do Acórdão de Mérito: 24/10/2018.

CAPPELLETTI, M.; GARTH, B. Access to Justice: A World Survey. Milano: Giuffrè, Sitjoff and Noordhoff, 1978.

CARROLL, J. S. The Effect of Imagining an Event on Expectations for the Event: An Interpretation in Terms of the Availability Heuristic. Journal of Experimental Social Psychology, v. 14, n. 1, 1978. p. 88-96:

CHABLO, A. What can artificial intelligence do for Anthropology? Current Anthropology, v. 37, p. 553-555, 1996.

CONSELHO NACIONAL DE JUSTIÇA. Justiça em números: 2018. Disponível em http://www.cnj.jus.br/files/ conteudo/arquivo/2018/08/44b7368ec6f888b383f6c3de40c32167.pdf. Acesso em: 21 maio 2019.

DIÁRIO INDÚSTRIA E COMÉRCIO. Fux diz que novo CPC elimina formalidades. Disponível em: https://www. diarioinduscom.com/fux-diz-que-novo-cpc-elimina-formalidades/. Acesso em: 11 maio 2019.

DREYFUS, H. L.; DREYFUS, S. E. Mind over machine: The power of human intuition Expertise in the era of the computer. New York, Free Press. 1986.

FREITAS, J.. Direito Administrativo e inteligência artificial. Interesse Público - IP, Belo Horizonte, ano 21, n. 114, p. 15 - 29, mar./abr. 2019

FRIEDMAN, M. There's no such thing as a free lunch. Chicago: Open Court Pub, 1975.

GALANTER, M. Access to justice in a world of expanding social capability, 37 Fordham Urb. L.J. 115, 2010.

GALANTER, M. Why the "haves" come out ahead: speculations on the limits of legal change. 9 Law \& Soc'y Rev., v. 95, 1974-1975.

GARAPON, A. O guardador de promessas: Justiça e Democracia. Lisboa: Instituto Piaget, 1996.

INSTITUTO DE PESQUISA ECONÔMICA APLICADA - IPEA. Custo Unitário do Processo de Execução Fiscal na Justiça Federal. Brasília: IPEA, 2012.

KAHNEMAN, D.; SLOVIC, P. (org.). Judgment under uncertainty: heuristics and biases. Cambridge: Cambridge University Press, 1982;

KUZNIETZ, G. Inteligência artificial no Direito chegou para ficar. Disponível em: https://www.jota. info/opiniao-e-analise/colunas/coluna-do-demarest/intelige ficar-05122018. Acesso em: 13 maio 2019.

MAIA FILHO, M. S.; JUNQUILHO, T. A. Projeto Victor: perspectivas de aplicação da inteligência artificial ao direito. Revista de Direitos e Garantias Fundamentais, Vitória, v. 19, n. 3, p. 219-238, set./dez. 2018.

MARINONI, L. G. Aproximação crítica entre as jurisdições de civil law e de common law e a necessidade de respeito aos precedentes no Brasil. Revista da Faculdade de Direito - UFPR., Curitiba, n.49, p. 11-58, 2009. 
MIESSA, É. Nova realidade: teoria dos precedentes e sua incidência no processo do trabalho. Revista eletrônica [do] Tribunal Regional do Trabalho da $9^{a}$ Região, Curitiba, PR, v. 5, n. 49, p. 9-57, abr. 2016.

NISBET, R. E.; ROSS, L. Human inference: strategies and shortcomings of social judgment. Englewood Cliffs, NJ: Prentice-Hall, 1980.

PERELMAN, C.. Ética e direito. Tradução de Maria Ermantina de Almeida Prado Galvão, 2. ed. São Paulo: Martins Fontes, 2005.

POHL, R. F. Cognitive Illusions: A Handbook on Fallacies and Biases in Thinking, Judgement and Memory, Hove: Psychology Press, 2004.

POUNDSTONE, W. Priceless: The myth of fair value.New York: Hill and Wang, 2010.

RHODE, Deborah. Access to Justice. London: Oxford University Press, 2004.

ROUSSEY, L.; SOUBEYRAN, R.. Overburdened Judges. International Review of Law and Economics, v. 55, September 2018. p.21-32.

ROSENBERG, D.. Mass tort class actions: What defendants have and plaintiffs don't. Harvard Journal on legislation, v. 37, p. 393-431, 2000.

SATHE, S.P. Judicial Activism in India: Transgressing borders and enforcing limits. Delhi: Oxford University Press, 2007.

SHAPIRO, M. M.; SWEET, A. S.. On Law, Politics, \& Judicialization. Oxford; New York: Oxford University Press, 2002.

SRULL, T.; WYER, R.. The role of category accessibility in the interpretation of information about persons: Some determinants and implications. Journal of Personality and Social Psychology, v. 37, n. 10, 1979. p. 1660-1672.

SUPERIOR TRIBUNAL DE JUSTIÇA. Banco de teses do Superior Tribunal de Justiça. Disponível em: https://scon. stj.jus.br/SCON/jt/. Acesso em: 20 ago. 2020.

SUPERIOR TRIBUNAL DE JUSTIÇA. Tema 939, Disponível em: http://www.stj.jus.br/repetitivos/temas_repetitivos/ pesquisa.jsp? novaConsulta $=$ true\&tipo_pesquisa $=$ T\&sg_classe $=$ REsp\&num_processo_classe $=1551951$.

Acesso em: 20 ago. 2020.

TATE, C. N.; VALLINDER, T.. The global expansion of judicial power. New York: New York University Press, 1995

TVERSKY, A.; KAHNEMAN, D.. Availability: A heuristic for judging frequency and probabilityCognitive Psychology, v. 2, n. 5, 1973. p. 207-232.

TVERSKY, A.; KAHNEMAN, D.. Extensional versus intuitive reasoning: The conjunction fallacy in probability judgment. Psychological Review, v. 90, n. 4, 1983. p. 293-315.

TRIBUNAL DE JUSTIÇA DE GOIÁS. Núcleo de Gerenciamento de Precedentes. Disponível em: https://www.tjgo. jus.br/index.php/nucleo-de-gerenciamento-de-precedentes-nugep/recursos-repetitivos. Acesso em: 20 ago. 2020.

TRIBUNAL DE JUSTIÇA DO RIO GRANDE DO SUL. Núcleo de Gerenciamento de Precedentes. Disponível em: https://www.tjrs.jus.br/novo/institucional/2o-grau/nugep/. Acesso em 20 de agosto de 2020.

VIANNA, L. W. A Judicialização da Política e das Relações Sociais no Brasil. Rio de Janeiro: Revan, 1999.

VILHENA, O. V.. Supremocracia. Revista Direito GV, São Paulo, n. 4, p. 441-464, jul./dez. 2008. 
VITORELLI, E.. Acordo coletivo dos planos econômicos e por que ele não deveria ser homologado. Disponível em: https://www.jota.info/paywall?redirect_to=//www.jota.info/opiniao-e-analise/artigos/acordocoletivo-dos-planos-economicos-e-por-que-ele-nao-deveria-ser-homologado-15012018. Acesso em: 21 maio 2019.

VITORELLI, E.. O devido processo legal coletivo: dos direitos aos litígios coletivos. São Paulo: RT, 2016.

VITORELLI, E.. Collective due process of law: Reconciling representation and participation. In: Cadiet, L.; Hess, B.; Requejo Isidro, M.. (org.). Approaches to Procedural Law The Pluralism of Methods. 1ed.Baden-Baden, Germany: Nomos, 2017. v. 1, p. 345-391.

ZAMIR, E.; TEICHMAN D. Behavioral law and economics. London: Oxford University Press, 2018.

ZIMMERMAN, G. Como advogar no século XXI. Disponível em: http://www.lex-net.com/new/como-advogarno-seculo-xxi/. Acesso em: 11 maio 2019.

ZUCKERMAN, Adrian (org.). Civil Justice in Crisis. London: Oxford University Press, 2000.

ANEXO

LISTA DE JULGADOS CONSULTADOS E CLASSIFICADOS 
Novos Estudos Jurídicos

\begin{tabular}{|c|c|c|c|c|}
\hline $\begin{array}{c}\text { Tribunal de } \\
\text { origem }\end{array}$ & $\begin{array}{c}\begin{array}{c}\text { Referência numérica } \\
\text { do caso }\end{array} \\
\end{array}$ & Ramo do Direito & Assunto/tese firmada & Classificação \\
\hline STJ & 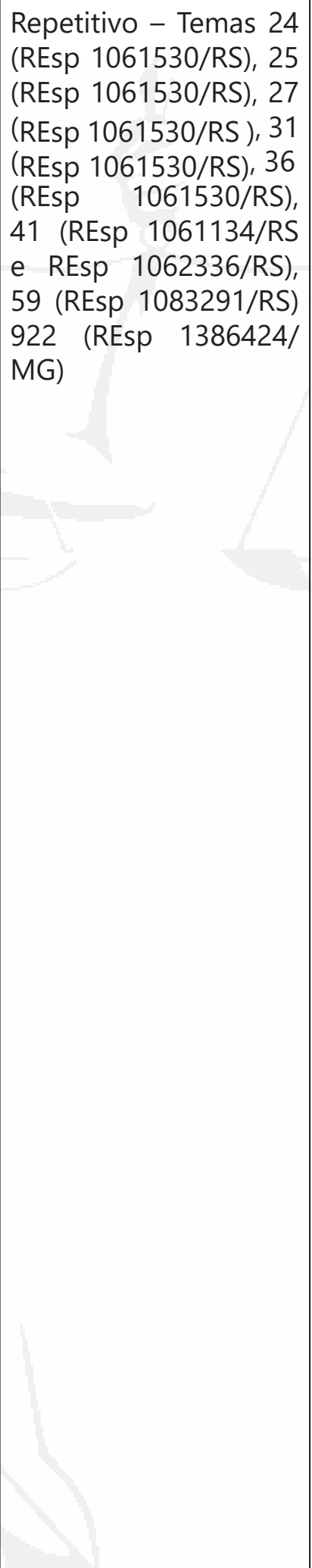 & Direito Bancário & $\begin{array}{l}\text { As instituições financeiras } \\
\text { não se sujeitam à limitação } \\
\text { dos juros remuneratórios } \\
\text { estipulada na Lei de Usura } \\
\text { (Decreto 22.626/33), } \\
\text { Súmula 596/STF. / A } \\
\text { estipulação de juros } \\
\text { remuneratórios superiores } \\
\text { a } 12 \% \text { ao ano, por si só, } \\
\text { não indica abusividade. / É } \\
\text { admitida a revisão das taxas } \\
\text { de juros remuneratórios } \\
\text { em situações excepcionais, } \\
\text { desde que caracterizada a } \\
\text { relação de consumo e que } \\
\text { a abusividade (capaz de } \\
\text { colocar o consumidor em } \\
\text { desvantagem exagerada } \\
\text { (art. } 51, \S 1 \text { o, do CDC) fique } \\
\text { cabalmente demonstrada, } \\
\text { ante às peculiaridades do } \\
\text { julgamento em concreto. } \\
\text { / Nos contratos bancários, } \\
\text { não-regidos por legislação } \\
\text { específica, os juros } \\
\text { moratórios poderão ser } \\
\text { convencionados até o limite } \\
\text { de } 1 \% \text { ao mês. / Da anotação } \\
\text { irregular em cadastro } \\
\text { de proteção ao crédito, } \\
\text { não cabe indenização } \\
\text { por dano moral, quando } \\
\text { preexistente legítima } \\
\text { inscrição, ressalvado o } \\
\text { direito ao cancelamento. } \\
\text { / A inscrição indevida } \\
\text { comandada pelo credor em } \\
\text { cadastro de inadimplentes, } \\
\text { quando preexistente } \\
\text { legítima anotação, não } \\
\text { enseja indenização por } \\
\text { dano moral, ressalvado o } \\
\text { direito ao cancelamento. } \\
\text { Inteligência da Súmula 385/ } \\
\text { STJ. }\end{array}$ & Restritiva \\
\hline
\end{tabular}




\begin{tabular}{|c|c|c|c|c|}
\hline $\begin{array}{c}\text { Tribunal de } \\
\text { origem }\end{array}$ & $\begin{array}{c}\text { Referência numérica } \\
\text { do caso }\end{array}$ & Ramo do Direito & Assunto/tese firmada & Classificação \\
\hline STJ & $\begin{array}{l}\text { Repetitivo - Tema } 30 \\
\text { (REsp 1061530/RS), } 37 \\
\text { (REsp 1061134/RS), } 40 \\
\text { (REsp 1062336/RS), } 52 \\
\text { (REsp 1058114/RS e } \\
\text { REsp 1063343/RS), } 411 \\
\text { (REsp 1133872/PB) e } \\
724 \text { (REsp 1391198/ } \\
\text { RS) }\end{array}$ & Direito Bancário & $\begin{array}{l}\text { Nos contratos bancários, } \\
\text { não-regidos por legislação } \\
\text { específica, os juros } \\
\text { moratórios poderão ser } \\
\text { convencionados até olimite } \\
\text { de } 1 \% \text { ao mês. / Os órgãos } \\
\text { mantenedores de cadastros } \\
\text { possuem legitimidade } \\
\text { passiva para as ações que } \\
\text { buscam a reparação dos } \\
\text { danos morais e materiais } \\
\text { decorrentes da inscrição, } \\
\text { sem prévia notificação, } \\
\text { do nome de devedor em } \\
\text { seus cadastros restritivos, } \\
\text { inclusive quando os os } \\
\text { dados utilizados para a } \\
\text { negativação são oriundos } \\
\text { do CCF do Banco Central } \\
\text { ou de outros cadastros } \\
\text { mantidos por entidade } \\
\text { diversas. / A ausência de } \\
\text { prévia comunicação ao } \\
\text { consumidor da inscrição } \\
\text { do seu nome em cadastros } \\
\text { de proteção ao crédito, } \\
\text { prevista no art. } 43 \text {, } 2^{\circ} \text {, } \\
\text { do CDC, enseja o direito à } \\
\text { compensação por danos } \\
\text { morais. / A cobrança de } \\
\text { comissão de permanência } \\
\text { - cujo valor não pode } \\
\text { ultrapassar a soma dos } \\
\text { encargos remuneratórios } \\
\text { e moratórios previstos } \\
\text { no contrato - exclui a } \\
\text { exigibilidade dos juros } \\
\text { remuneratórios, moratórios } \\
\text { e da multa contratual. }\end{array}$ & Multiplicativa \\
\hline
\end{tabular}


Novos Estudos Jurídicos

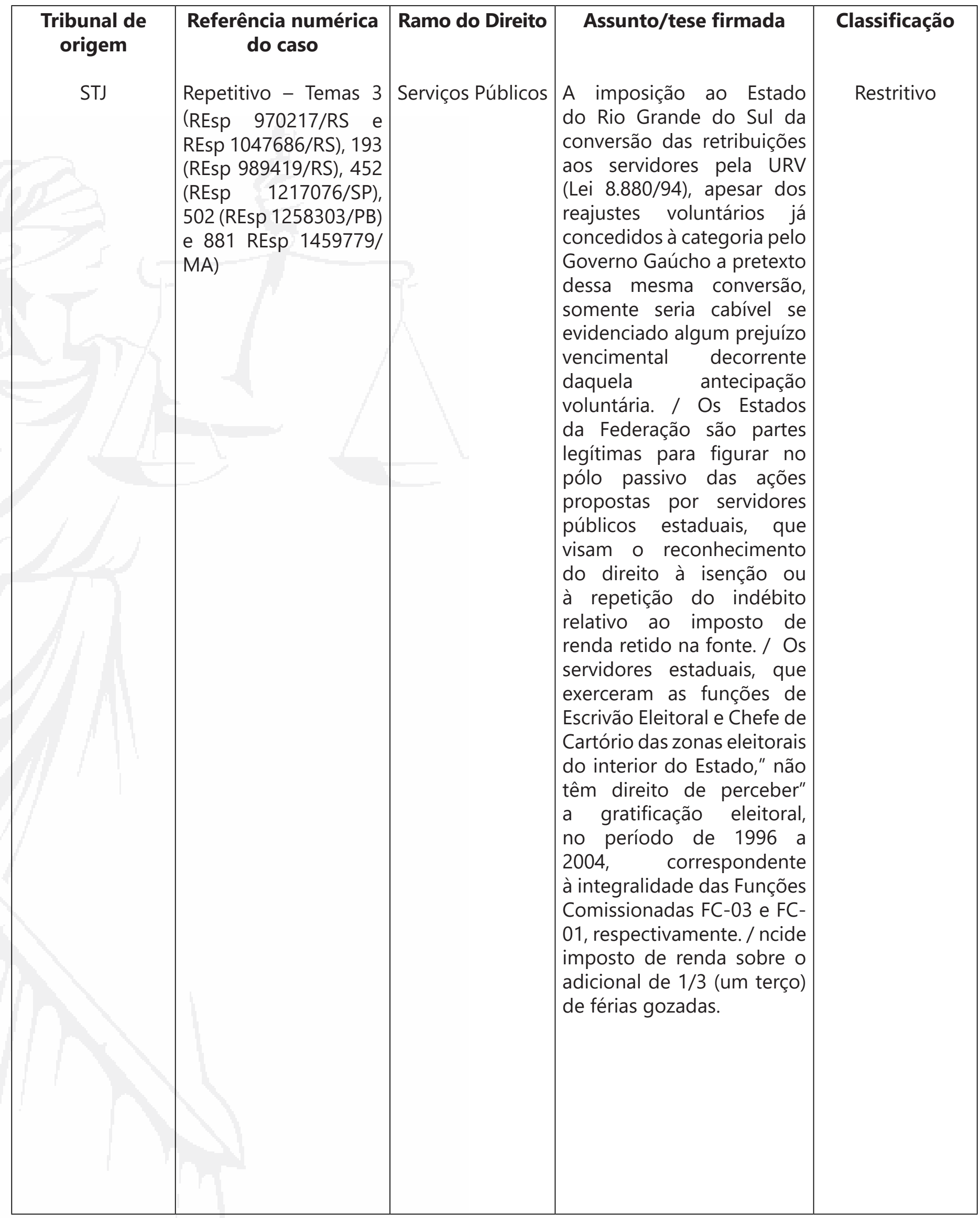


Novos Estudos Jurídicos

\begin{tabular}{|c|c|c|c|c|}
\hline $\begin{array}{c}\text { Tribunal de } \\
\text { origem }\end{array}$ & \begin{tabular}{|c|}
$\begin{array}{c}\text { Referência numérica } \\
\text { do caso }\end{array}$ \\
\end{tabular} & Ramo do Direito & Assunto/tese firmada & Classificação \\
\hline STJ & $\begin{array}{l}\text { Repetitivo - Temas } \\
745 \text { (REsp 1235513/AL) } \\
\text { e } 531 \text { (REsp 1244182/ } \\
\text { PB) }\end{array}$ & Serviços Públicos & 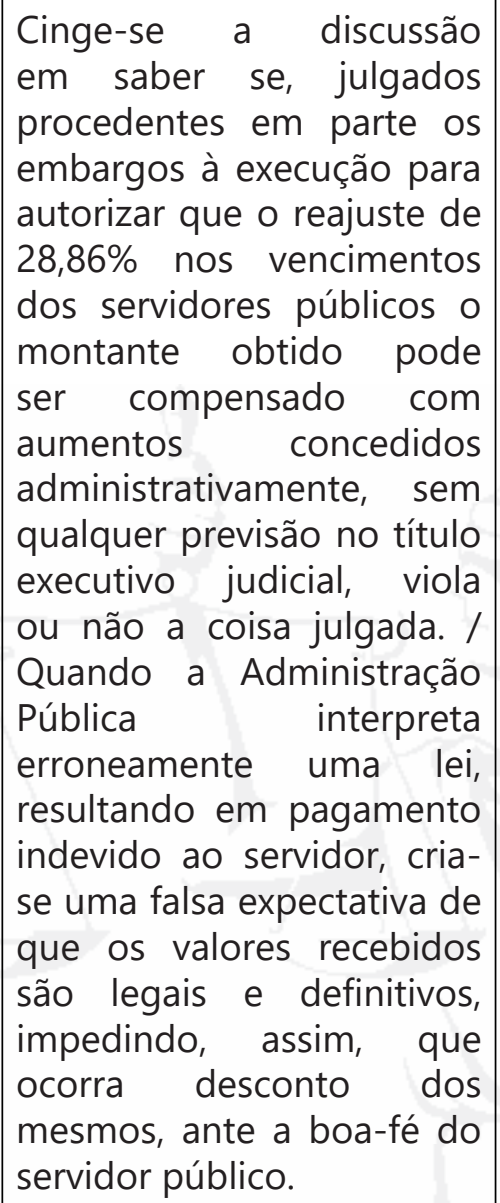 & Multiplicativo \\
\hline
\end{tabular}




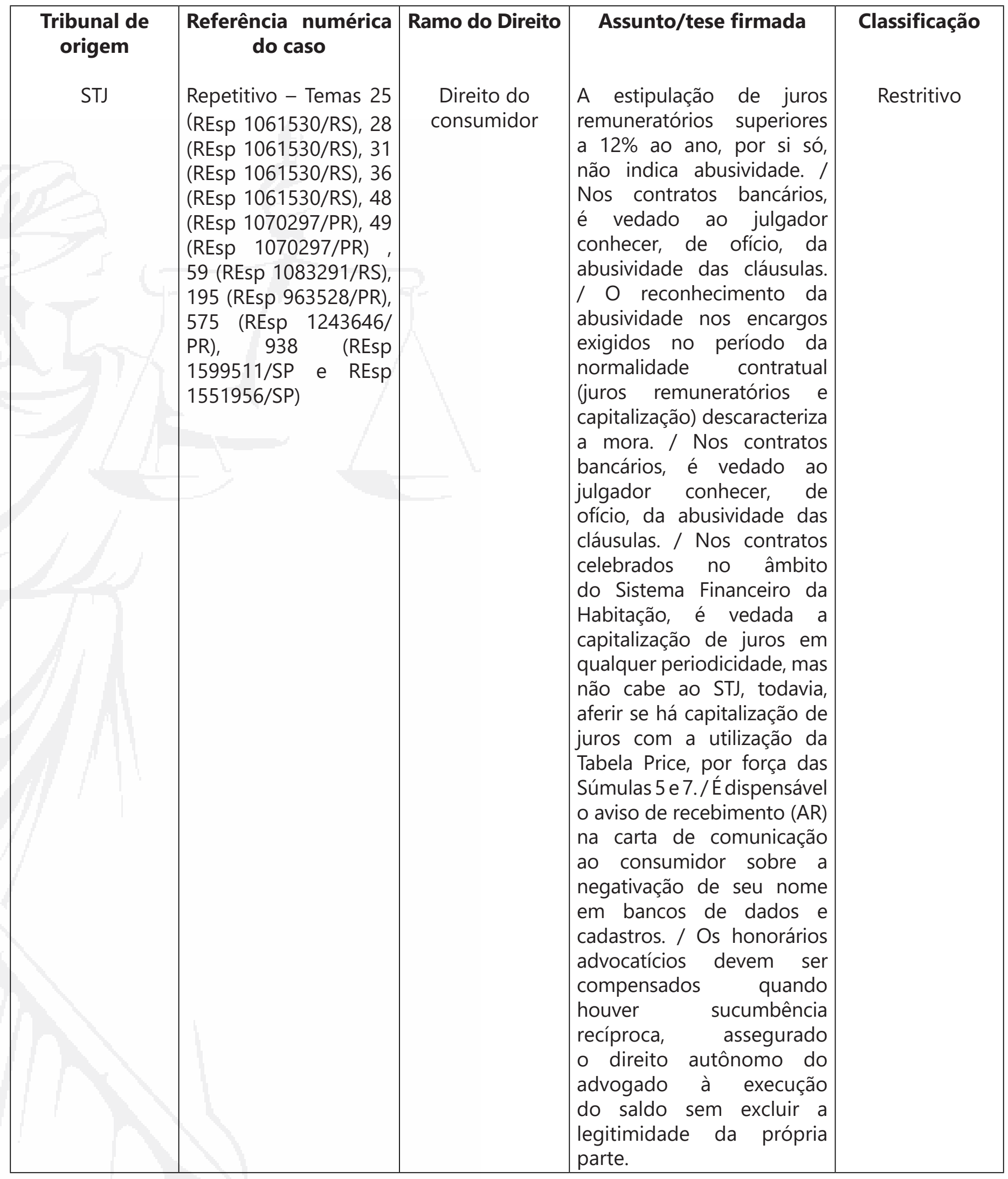




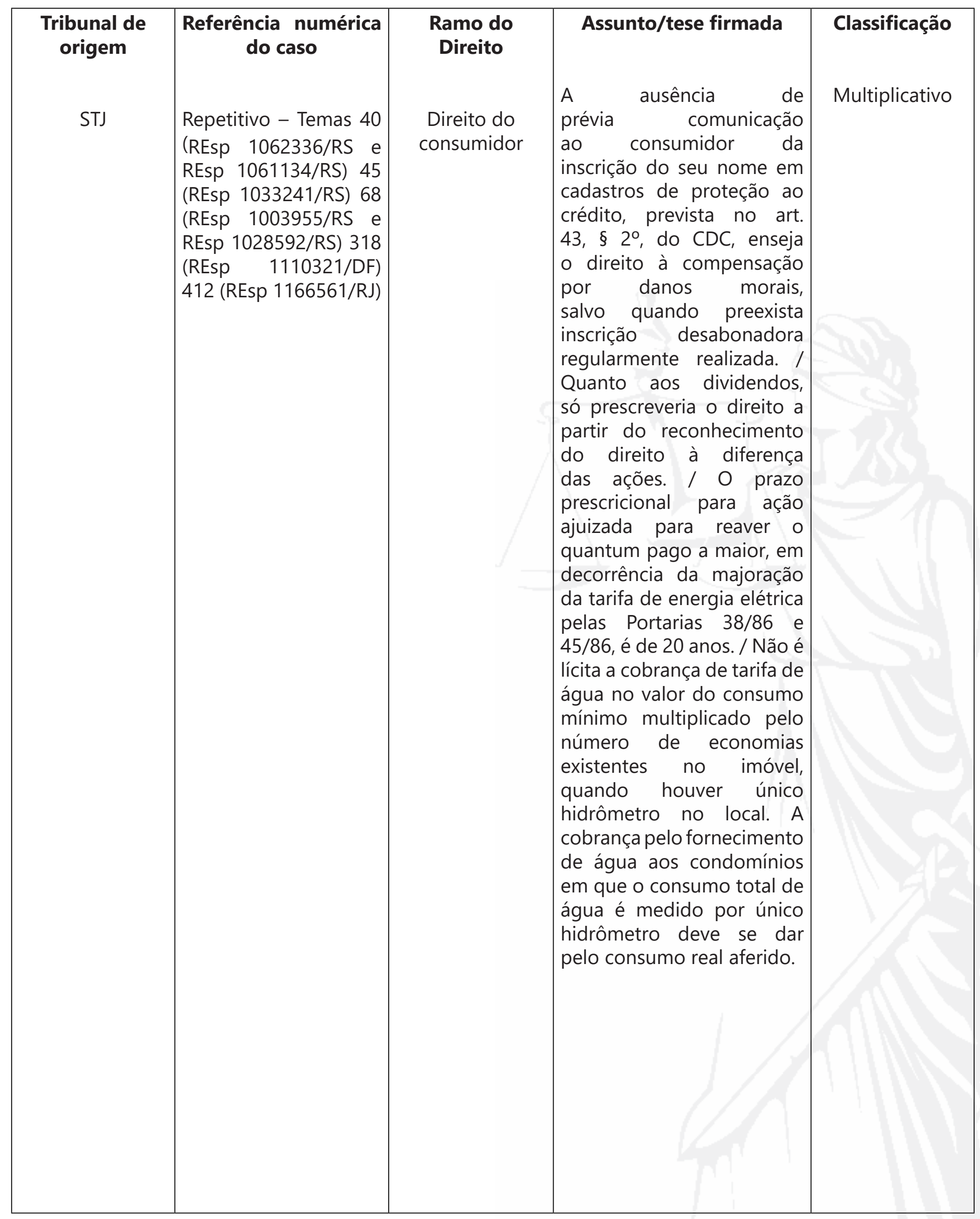




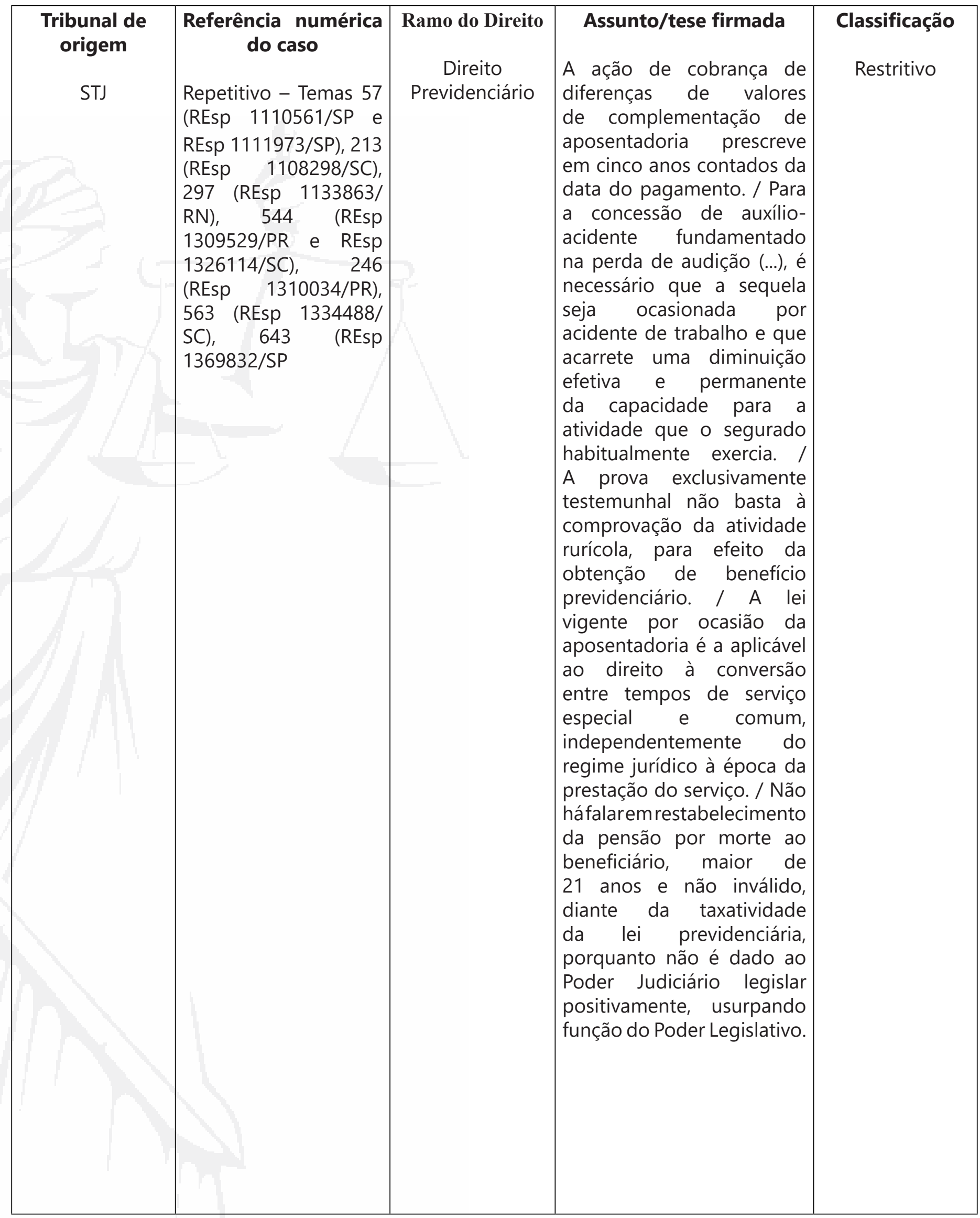




\begin{tabular}{|c|c|c|c|c|}
\hline $\begin{array}{c}\text { Tribunal de } \\
\text { origem } \\
\text { STJ }\end{array}$ & 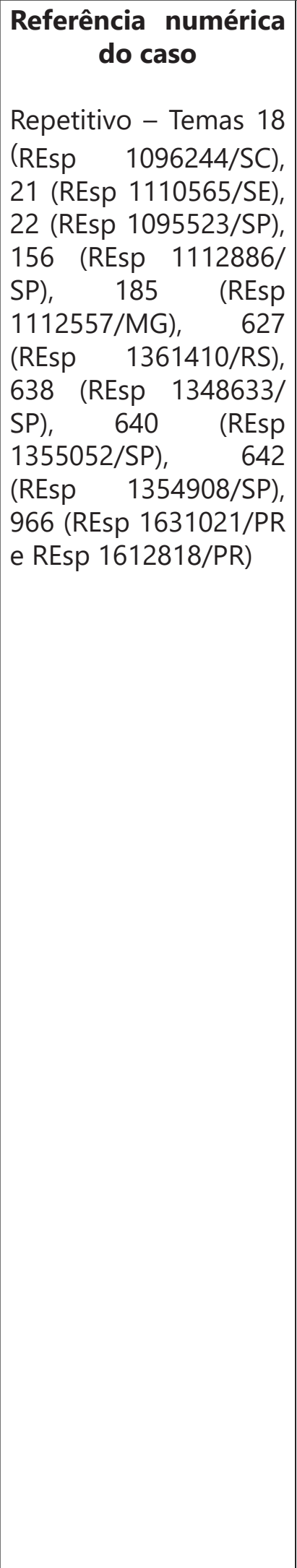 & $\begin{array}{c}\text { Ramo do } \\
\text { Direito } \\
\text { Direito } \\
\text { Previdenciário }\end{array}$ & 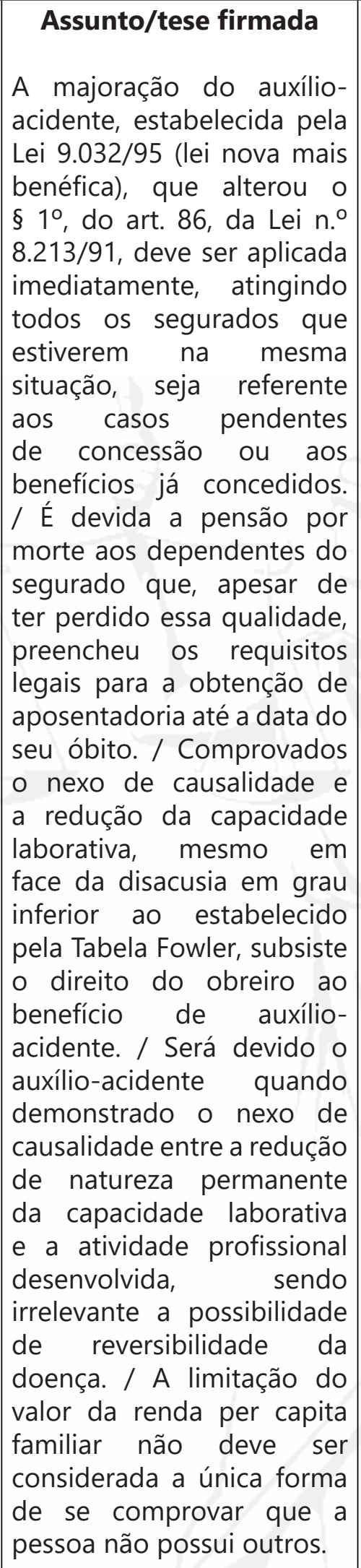 & $\begin{array}{l}\text { Classificação } \\
\text { Multiplicador }\end{array}$ \\
\hline
\end{tabular}


Tabela 2

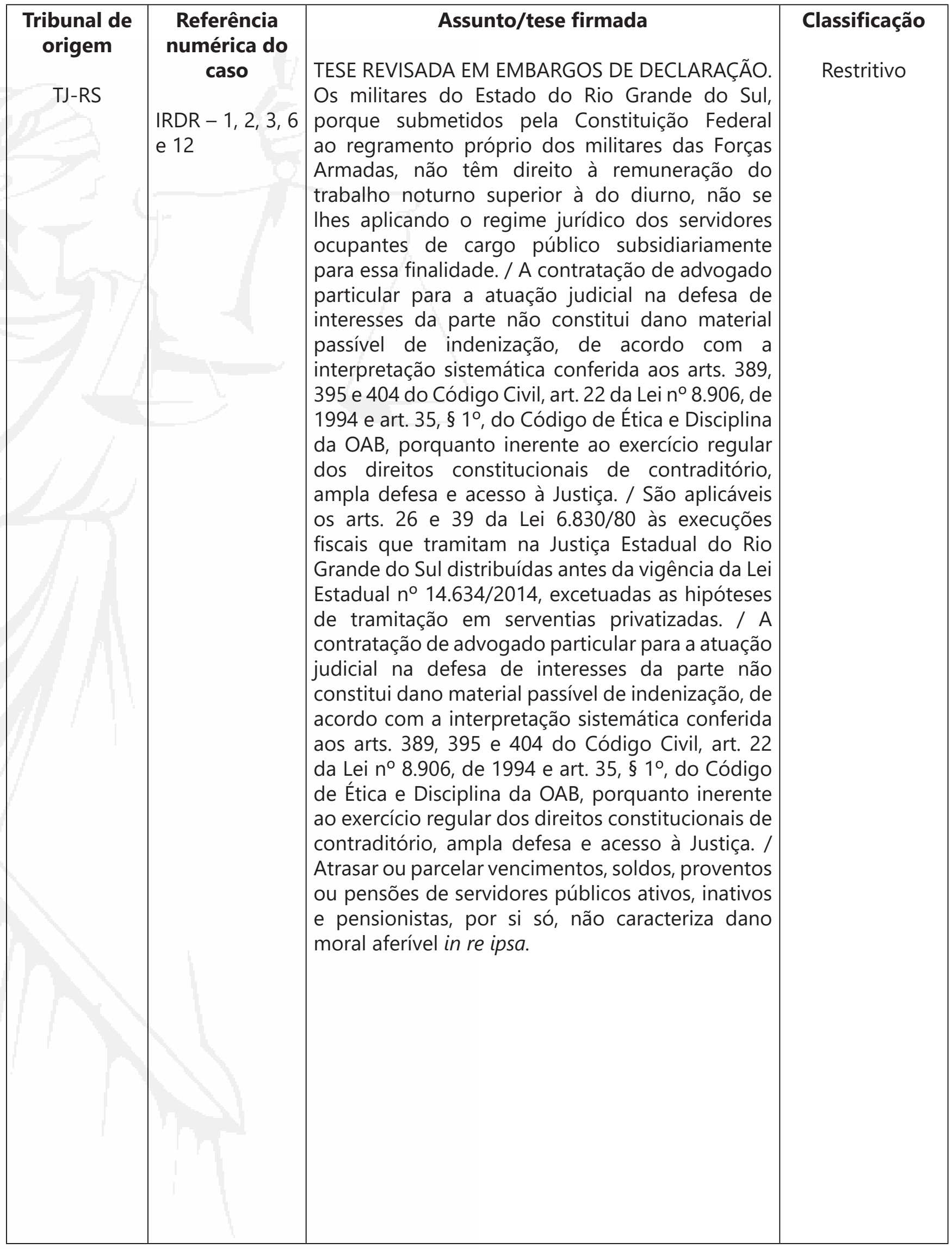




\begin{tabular}{|c|c|c|c|}
\hline $\begin{array}{c}\text { Tribunal de } \\
\text { origem } \\
\text { TJ-RS }\end{array}$ & $\begin{array}{c}\text { Referência } \\
\text { numérica do } \\
\text { caso } \\
\text { IRDR - } 4\end{array}$ & $\begin{array}{l}\text { Assunto/tese firmada } \\
\text { Tratando-se de conflito de competência entre os } \\
\text { foros da capital, o litígio deve tramitar naquele } \\
\text { escolhido pelo consumidor desde que observada } \\
\text { uma das condições legais, descabendo declinação } \\
\text { de ofício. }\end{array}$ & $\begin{array}{l}\text { Classificação } \\
\text { Multiplicativo }\end{array}$ \\
\hline $\begin{array}{c}\text { Tribunal de } \\
\text { origem } \\
\text { TJ-GO }\end{array}$ & $\begin{array}{c}\begin{array}{c}\text { Referência } \\
\text { numérica do } \\
\text { caso }\end{array} \\
\text { IRDR - } 1 \text { e } 4\end{array}$ & $\begin{array}{l}\text { Assunto/tese firmada } \\
1 \text { - Para configuração do dano moral, causado pela } \\
\text { concessionária de serviço público que responde } \\
\text { objetivamente por seusatos, deve ser demonstrado } \\
\text { pelo consumidor a existência do dano e o nexo de } \\
\text { causalidade entrea conduta da empresa e o prejuízo } \\
\text { sofrido. Somente em situações que efetivamente } \\
\text { lesionem os direitos da personalidade, causando } \\
\text { real sofrimento às vítimas, podem fundamentar } \\
\text { a indenização por dano moral, sob pena de se } \\
\text { comutar em fonte de locupletamento ilícito. } \\
2 \text { - Na hipótese de configuração de dano moral } \\
\text { ao consumidor, o Juiz a quo deve fixar o valor da } \\
\text { reparação à luz das circunstâncias fáticas provadas } \\
\text { no processo, considerando, como ponto de } \\
\text { partida, os precedentes deste eg. Tribunal e do } \\
\text { c. STJ, em casos semelhantes, sem descurar do } \\
\text { aspecto punitivo e pedagógico da condenação. / } \\
\text { Em ação de cobrança ajuizada por concessionária } \\
\text { prestadora de serviços públicos de água e esgoto, } \\
\text { independentemente de pedido expresso, incluem- } \\
\text { se na condenação as parcelas vencidas e as que } \\
\text { se vencerem no curso do processo, inclusive a } \\
\text { 'tarifa mínima fixa', até o efetivo pagamento, } \\
\text { postergando-se a apuração do quantum devido } \\
\text { para a fase de liquidação, quando a credora deverá } \\
\text { apresentar as respectivas faturas. }\end{array}$ & $\begin{array}{c}\text { Classificação } \\
\text { Restritivo }\end{array}$ \\
\hline
\end{tabular}


Novos Estudos Jurídicos

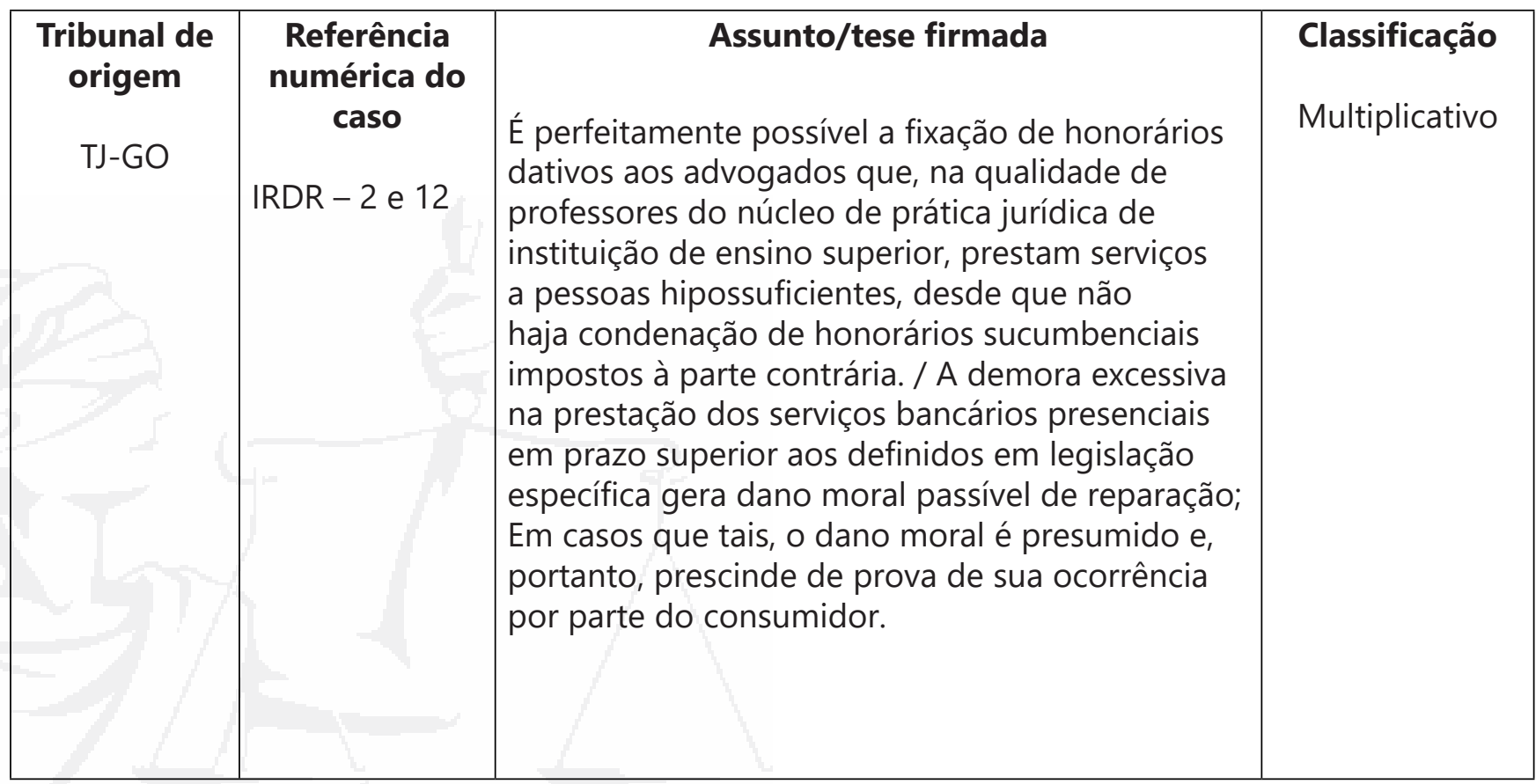

Recebido em: 08/06/2020

Aprovado em: 17/11/2020 